\title{
Faktor - Faktor Yang Berhubungan Dengan Kecemasan Pada Wanita Usia Subur Terhadap Pemeriksaan IVA di Puskesmas Bula Kecamatan Bula Kabupaten Seram Bagian Timur
}

\author{
Rini Kundaryanti, Triana Indrayani, Dian Irawati \\ Universitas Nasional, Jakarta, Indonesia \\ Corresponding author: Triana Indrayani (trianaindrayani21@gmail.com) \\ Received: December, 16 2019; Accepted: January, 19 2020; Published: March, 152020
}

\begin{abstract}
ABSTRAK
Berdasarkan data Dinas Kesehatan Kabupaten Seram Bagian Timur tahun 2017 di Puskesmas Bula jumlah wanita usia subur yang datang untuk memeriksa IVA sebanyak 1.396 wanita, dan yang berminat untuk memeriksa IVA sebanyak 113 wanita. Metode yang digunakan adalah cross sectional. Populasi dalam penelitian ini adalah semua wanita usia subur yang memeriksakan IVA di Puskesmas Bula Kecamatan Bula Kabupaten Seram Bagian Timur Tahun 2018. Hasil sampel yang di dapat 89 responden. Penelitian ini diperoleh 4 variabel yang berhubungan dengan kecemasan pemeriksaan IVA yaitu pengetahuan $(0,040)$, paritas $(0,047)$, pendapatan keluarga $(0,044)$, sumber informasi tenaga kesehatan $(0,036)$, pengetahuan yang kurang $<76 \%$ beresiko 3,100 kali mengalami kecemasan dibandingkan dengan pengetahuan baik $\geq 76 \%$.

Ada hubungan antara pengetahuan, paritas, pendapatan keluarga dan sumber informasi Tenaga Kesehatan dengan kecemasan pemeriksaan IVA di Puskesmas Bula Kecamatan Bula Kabupaten Seram Bagian Timur Tahun 2018. Disarankan untuk tenaga kesehatan meningkatkan frekuensi promosi kesehatan kepada seluruh wanita usia subur.
\end{abstract}

Kata Kunci: Wanita Usia Subur, Pengetahuan, Paritas, Pendapatan Keluarga, Sumber Informasi Tenaga Kesehatan

This is an open-acces article distributed under the terms of the Creative Commons Attribution-ShareAlike 4.0 International License.

\section{PENDAHULUAN}

Kanker serviks atau kanker leher rahim merupakan salah Satu kanker yang paling sering menyerang wanita di seluruh dunia, bahkan menurut WHO, kanker serviks menempati urutan kedua sebagai penyebab kematian terbanyak setelah penyakit kardiovaskuler (kementrian kesehatan RI, 2015). Kanker serviks ini di sebabkan oleh infeksi dari human papiloma virus, biasanya terjadi pada perempuan usia subur. HPV di tularkan melalui hubungan seksual dan ditemukan pada 95\% kasus kanker serviks (Kumalasari, 2014).

Menurut (World Health Organization) tahun 2017, jumlah data pengidap kanker tahun 2016 ada 17,8 juta jiwa dan tahun 2017 menjadi 21,7 juta jiwa. Terjadi peningkatan 3,9 persen jumlah pengidap kanker, "beber dia. Bahkan, lanjut Aru, menurut WHO padatahun 2030 akan terjadi lonjakan penderita kanker di Indonesia sampai 7 kali lipat. Jumlah 
penderita kanker yang meninggal juga kian memprihatinkan. Di Indonesia, setiap tahun terdeteksi lebih dari 15.000 kasus kanker serviks, dan sekitar 8.000 kasus di antaran yang meninggal dunia setiap satu menit muncul kasus baru dan setiap menit meninggal 1 orang perempuan ( Sheriah, 2014).

Angka kejadian kanker serviks di Indonesia tahun 2014 mencapai 2 angka 100 per 100.000 penduduk pertahun, dan penyebaran terlihat terakumulasi di Jawa dan Bali. Angka ini di prediksi akan terus meningkat $25 \%$ dalam kurun waktu 10 tahun mendatang jika tidak segera di lakukan upaya pencegahan (Rasjidi, 2015).

Berdasarkan data profil dinas kesehatan provinsi Maluku, jumlah kasus kanker serviks menunjukan angka yang cukup tinggi dan meningkat setiap tahunnya. Proporsi penyakit kanker serviks meningkat dari tahun 2014 dan 2015, masing-masing sebesar 2.259 kasus $(19,92 \%)$ menjadi 2.295 kasus $(25,10 \%)$ tahun 2014 sebesar 2.350 kasus $(31,23 \%)$. Kasus tersebut menimbulkan kematian wanita di Negara berkembang mencapai $>85 \%$ (Dinkes Provinsi Maluku, 2014).

Pada 92\% lesi prakanker tidak terdapat gejala dan kalaupun ada hanya berupa rasa kanker di vagina, atau keputihan berulang meskipun sudah diobati (Samadi, 2014). Perkembangan kanker serviks ini membutuhkan waktu yang lama, artinya mulai infeksi virus sampai menjadi kanker membutuhkan waktu 3 sampai 14 tahun, atau 3 rata-rata hampir 10 tahun. Kanker serviks ini juga berkembang secara bertahap, artinya adanya fase prakanker yang jika di temukan lebih awal dan diobati dengan baik akan sembuh 100\% (Samadi, 2015). Infeksi HPV terjadi pada perempuan usia produktif. Infeksi ini dapat menetap, berkembang menjadi dysplasia atau sembuh sempurna.Virus ini di temukan pada 95\% kasus cankers erviks. Proses terjadinya kanker serviks sangat erat berhubungan dengan proses metaplasia. Masuknya mutagen atau bahan bahan yang dapat mengubah perangai sel secara genetic pada fase aktif metaplasia dapat berubah menjadi sel yang berpotensi ganas.Sel yang mengalami mutasi disebut sel displastik dan kelainan epitelnya disebut displasia (Neoplasiaintraepitelserviks/NIS).

Berdasarkan survei pendahuluBerdasarkan data Dinas Kesehatan Kabupaten Seram BagianTimur tahun 2017 di Puskesmas Bula jumlah wanita usia subur yang datang untuk di periksa IVA sebanyak 1.396 wanita, dan yang berminat memeriksa sebanyak 113 wanita.Sehingga penulis ingin meneliti dengan judul "faktor-faktor yang berhubungan dengan kecemasan pada wanita usia subur terhadap pemeriksaan IVA di Puskesmas Bula Kecamatan Bula Kabupaten Seram Bagian Timur Tahun 2018”.

\section{METODE}

Desain penelitian ini adalah penelitian Analitik yang bertujuan untuk mengungkapkan hubungan korelatif dua variabel yaitu menghubungkan antara variable independen dan variable dependen (Notoatmodjo, 2010).

Penelitianini menggunakan pendekatan Cross sectional yaitu dengan model pendekatan atau pengukuran variabel pada suatu saat tertentu atau pada saat yang sama dan pengumpulan serta pengambilan data yang dilakukan hanya sekali.

Penelitian ini bertempat di Puskesmas Bula Kecamatan Bula Kabupaten Seram Bagian Timur pada bulan Oktober 2018 - Maret 2019.

Sampel adalah sebagian yang diambil dari keseluruhan objek yang diteliti dan dianggap mewakili seluruh populasi (Notoatmodjo, 2012). Sampel yang diambil dalam penelitian ini adalah 89 responden.

\section{HASIL}

Berdasarkan hasil uji statistik chi square, diperoleh nilai $\mathrm{p}$ value $=0,040<\alpha(0,05)$ data hasil ini menunjukan bahwa ada hubungan yang bermakna antara pengetahuan dengan kecemasan 
pemeriksaan IVA pada wanita usia subur dan pengetahuan yang kurang $<76 \%$ beresiko 3,100 kali mengalami kecemasan dibandingkan dengan pengetahuan baik $\geq 76 \%$. Dari 38 responden yang pengetahuan baik $\geq 76 \%$ yang cemas sebanyak $31(81,6 \%)$ responden dan responden yang tidak cemas sebanyak $7(18,4 \%)$ responden. Sedangkan dari 51 responden pengetahuan kurang $<76 \%$ yang cemas sebanyak $30(58,8 \%)$ responden, dan responden tidak cemas IVA sebanyak $21(41,2 \%)$ responden.

Tabel 1. Hasil Bivariat Hubungan Antara Pengetahuan Dengan Kecemasan Wanita Usia subur terhadap Pemeriksaan IVA

\begin{tabular}{|c|c|c|c|c|c|c|c|c|}
\hline \multirow{3}{*}{$\begin{array}{c}\text { Pengetahua } \\
n\end{array}$} & \multicolumn{4}{|c|}{ Kecemasan } & \multirow{2}{*}{\multicolumn{2}{|c|}{ Total }} & \multirow[t]{2}{*}{$P$ Value } & \multirow[t]{2}{*}{ OR } \\
\hline & \multicolumn{2}{|c|}{ Cemas } & \multicolumn{2}{|c|}{ Tidak cemas } & & & & \\
\hline & $\Sigma$ & $\%$ & $\Sigma$ & $\%$ & $\Sigma$ & $\%$ & \multirow{4}{*}{0,040} & \multirow{4}{*}{3,10} \\
\hline Baik $\geq 76 \%$ & 31 & 81,6 & 7 & 18,4 & 38 & 100 & & \\
\hline $\begin{array}{c}\text { Kurang }< \\
76 \%\end{array}$ & 30 & 58,8 & 21 & 41,2 & 51 & 100 & & \\
\hline Total & 61 & 68,5 & 28 & 31,5 & 89 & 100 & & \\
\hline
\end{tabular}

\section{PEMBAHASAN}

Analisis Bivariat

Hubungan Antara Pengetahuan Pada Wanita Usia subur terhadap Pemeriksaan IVA di Puskesmas Bula Kecamatan Bula Kabupaten Seram Bagian Timur Tahun 2018

Berdasarkan hasil uji statistik chi square, diperoleh nilai $p$ value $=0,040<\alpha(0,05)$ data hasil ini menunjukan bahwa ada hubungan yang bermakna antara pengetahuan dengan kecemasan pemeriksaan IVA pada wanita usia subur dan pengetahuan yang kurang $<76 \%$ beresiko 3,100 kali mengalami kecemasan dibandingkan dengan pengetahuan baik $\geq 76 \%$.

Dari 38 responden yang pengetahuan baik $\geq 76 \%$ yang cemas sebanyak $31(81,6 \%)$ responden dan responden yang tidak cemas sebanyak $7(18,4 \%)$ responden. Sedangkan dari 51 responden pengetahuan kurang $<76 \%$ yang cemas sebanyak $30(58,8 \%)$ responden, dan responden tidak cemas IVA sebanyak $21(41,2 \%)$ responden.

Secara garis besar menurut Notoatmodjo (2014), domain tingkat pengetahuan (kognitif) mempunyai enam tingkatan, meliputi: mengetahui,memahami,menggunakan, menguraikan, menyimpulkan dan mengevaluasi. Ciri pokok dalam taraf pengetahuan adalah ingatan tentang sesuatu yang diketahuinya baik melalui pengalaman, belajar, ataupun informasi yang diterima dari orang lain. Pengetahuan adalah hasil "tahu" dan ini terjadi sesudah orang tersebut melakukan penginderaan terhadap suatu objek tertentu. Penginderaan terjadi lewat panca indera manusia yakni indera penciuman, pendengaran, penglihatan, rasa dan raba. Sebagian besar pengetahuan manusia didapatkan lewat mata dan telinga (Soekidjo, Notoadmodjo 2014). Hasil penelitian yang dilakukan oleh Indah Siti Lestari WUS di wilayah kerja puskesmas Manahan Kota Surakarta mempunyai pengetahuan yang baik yaitu sebanyak 86 orang $(36,4 \%)$ dan WUS yang berpengetahuan kurang sebanyak 150 orang $(63,6 \%)$. Faktor yang ikut berperan dalam melakukan deteksi dini kanker serviks yaitu sikap, dimana WUS di wilayah kerja puskesmas Manahan sebagian besar yaitu 122 orang $(51,7 \%)$ mempunyai sikap yang tidak baik terhadap deteksi dini kanker serviks.

Hasil penelitian yang dilakukan oleh Putri Rizki M terdapat peningkatan pengetahuan responden yang sebelumnya tingkat pengetahuan responden baik sebanyak 33 responden (42.3\%) setelah diberikan pendidikan kesehatan meningkat menjadi 57 responden $(73,1 \%)$. Begitu pula dengan sebaliknya dengan tingkat pengetahuan kurang yang sebelumnya 45 responden $(57,7 \%)$ setelah diberikan pendidikan kesehatan mengalami penurunan menjadi 21 responden $(26,9 \%)$ 
Menurut peneliti pengetahuan sangat besar pengaruhnya terhadap pemeriksaan IVA pada wanita usia subur. Karena semakin banyaknya ilmu atau pengetahuan yang di dapat maka semakin tahu baik buruknya pemeriksaan IVA.

\section{KESIMPULAN}

Berdasarkan hasil penelitian tentang faktor - faktor yang berhubungan dengan kecemasan pada wanita usia subur terhadap pemeriksaan IVA Di Puskesmas Bula Kecamatan Bula Kabupaten Seram Bagian Timur Tahun 2018. Maka didapatkan kesimpulan sebagai berikut :

1. Dari 89 responden yang memeriksakan IVA Di Puskesmas Bula Kecamatan Bula Kabupaten Seram Bagian Timur Tahun 2018 didapatkan yang tidak memeriksakan IVAsebanyak 61 (68,5\%) .

2. Ada hubungan yang signifikan antara pengetahuan, paritas, pendapatan keluarga, sumber informasi tenaga kesehatan, dengan pemeriksaan IVA Di Puskesmas Bula Kecamatan Bula Kabupaten Seram Bagian Timur Tahun 2018.

3. Variabel yang paling berpengaruh terhadap pemeriksaan IVA trimester I Di Puskesmas Bula Kecamatan Bula Kabupaten Seram Bagian Timur Tahun 2018 adalah pengetahuan yang kurang $<76 \%$ beresiko 3,100 kali mengalami kecemasan dibandingkan dengan pengetahuan baik $\geq 76 \%$.

\section{REFERENSI}

American cancer society. 2014. Cancer Fact and Figures 2014, diambil dari http://www.cancer.org/research/cancerfactsstatistics/cancerfactsfigures2014/yang diakses tanggal 8 Desember 2015.

Anwar, Syaifuddin. 2005. Sikap Manusia : Teori dan Pengukurannya. Yogyakarta : Pustaka Pelajar. Anwar, Syaifuddin. 2009. Sikap Manusia Teori dan Pengukurannya. Yogyakarta : Pustaka Pelajar.

Arum S.P. (2015). Stop Kanker Serviks. Jakarta : Buku Kita..

Benson., Ralph C dan Martin L Pernoll. (2014). BukuSaku Obstetric Dan Ginokologi. Jakarta: EGC

Basu,et al. (2014). Knowledge,Attitude And Practices Of Women In Maldives Related To The Risk Factors, Prevention And Early Detection Of Cervical Cancer. Diakses Pada Tanggal 23 Maret 2017 Melalui http://dx.doi.org/10.7314/APJCP.2014.15.16.6691

Depkes RI. 2015. Infodatin : Stop Kanker, diambil dari http://www.depkes. go.id/resources/download/pusdatin/infodatin/infodatin-kanker.pdf yang diakses tanggal 6 Desember 2015. Jakarta : Pusat data dan informasi kementrian kesehatan RI. DKK Sukoharjo. 2015. Kanker Serviks, yang diambil dari http:// http://dkk. sukoharjokab.go.id/read/kanker-serviks yang diakses tangal 6 Desember 2015.

Depkes. 2008 SkriningKankerLeher Rahim DenganMetodeInspeksi Visual DenganAsamAsetat (IVA).DepartemenKesehatanRepoblik Indonesia

Dinas Kesehatan.Direktora Pengendalian Penyakit Tidak Menular. Buku Saku Pencegahan Kanker Leher Rahim\& Dan Kanker Payudara.Diakses Pada Tanggal 27 Maret 2017

Fajriati, et All. (2013). Hubungan Dukungan Sosial dengan Tingkat Kecemasan pada Pasien Kanker yang akan Menjalani Kemoterapi di RS Roemani Semarang. JURMA, 1(1).

Friedman, M.M, Bowden, O. \& Jones, M. (2010). Buku Ajar Keperawatan Keluarga : riset, teori, \& praktik. Jakarta : EGC.

Goleman, D. (2003). Kecerdasan Emosional. Jakarta : Gramedia Pustaka Utama. 
Globocan-IARC. (2014). Estimated cancer incidence, mortality and prevalence worldwide in 2012. International Agency for Research on Cancer, World Health Organization. http://globocan.iarc.fr/Pages/fact_sheets_cancer.aspx. [12 Februari 2017]

Infodatin. (2015). Stop Kanker : Situasi Penyakit Kanker. Jakarta : Kemenkes RI.

Juanda, D. \& Kesuma, H Solusi Cerdas Mencegah dan Mengobati Kanker.. (2015). Pemeriksaan Metode IVA (Inspeksi Visual Asam Asetat) untuk Pencegahan Kanker Serviks. Jurnal Kedokteran dan Kesehatan, 2(2):169-174.

Kartikawati, E. (2013). Awas!!! Bahaya Kanker Payudara dan Kanker Serviks. Buku Baru: Bandung

Maharani, S. (2009). Kanker: Mengenal 13 Jenis Kanker dan Pengobatannya. Yogyakarta: Katahati.

Notoadmodjo S. 2013. Promosi Kesehatan dan Ilmu Perilaku. Jakarta : Rineka Cipta

Notoatmodjo S. (2014). Metodologi Penelitian Kesehatan. Jakarta : Rineka Cipta

Notoatmodjo, S. (2015). Metode Penelitian Kesehatan. Jakarta : EGC

Notoatmodjo, S. (2015). Kesehatan Masyarakat . Jakarta : EGC

Nugroho, et all. 2015. Buku Ajar Obstentri Untuk Mahasiswa Kebidanan. Yogyakarta : Nuha Medika.

Nugroho, T dan Bobby I.U, 2014. Masalah Kesehatan Reproduksi Wanita.NuhaMedika : Yogyakarta

Rasjidi,et all. 2016. Deteksi Dini dan Penceahan Kanker Pada Wanita. Jakarta : Sagung Seto

Rostia, et all. 2016. Jakarta : Agromedia Pustaka. P

Sari, at all. 2016. Paduan Lengkap Kesehatan Wanita. Jakarta : Penebar Plus

Sisca Nida Mayrita (2014) Hubungan antara Paritas dengan Kejadian kanker Serviks

Stuart \& Sundeen. (1998). Buku Saku Keperawatan Edisi 3. Jakarta : EGC

Sugiyono. 2014. Metode Penelitian Kuantitatif, Kualitatif dan R\&D. Bandung : Alfabeta

Suryabrata, Sumadi. 2014. Psikologi Pendidikan. Jakarta : Rajawali.

Swarjana, I.K. (2012). Metodologi Penelitian Kesehatan. Andi Offset: Yogyakarta.

Tilong, Adi D., 2015. Bebas Dari Ancaman Kanker Serviks. Yogyakarta : Flashbook

Videbeck, S.L. (2008). Buku Ajar Keperawatan Jiwa. Jakarta: EGC

Walgito, B. (2002). Pengantar Psikologi Umum. Yogyakarta: Andi Offset.

World Health Organization. 2014. Cancer, diambil dari http://www.who.int /cancer/en/index.html1 yang diambil pada 8 Desember 2015.

Widowati, P.C. (2009). Hubungan Antara Kematangan Emosi dengan Perilaku Seksual Pranikah Pada remaja Akhir. Skripsi Fakultas Psikologi Universitas Sanata Dharma.

Yolanda, A.E \& Karwur, F.F. (2013). Tingkat Kecemasan Pasien Kanker Serviks pada Golongan Ekonomi Rendah yang Mengikuti Program Kemoterapi di RSUD Dr. Moewardi. Sains Medika, 2(5):68-81

http://eprints.ums.ac.id/45708/18/Naspub_indah.pdf

https://studylibid.com/doc/526542/gambaran-tingkat-kecemasan-ibu-dalam-melakukan

http://eprints.ums.ac.id/46217/1/NASKAH\%20PUBLIKASI.pdf

http://digilib.unisayogya.ac.id/417/1/NASKAH\%20PUBLIKASI\%20SKRIPSI\%20Dini\%20An

driyani\%2C\%20Fathiyatur\%20Rohmah.pdf 
https://www.neliti.com/id/publications/13499/judul-hubungan-tingkat-pengetahuan-dansikap-wanita-usia-subur-wus-dengan-pemeriksaan IVA

ttps://ejurnal.stikesmhk.ac.id/index.php/jurnal_ilmiah_maternal/article/viewFile/568/507

http://ejurnal.rizki.dewi.pendapatankeluargadeng ankecemasanpemeriksaan IVA 2017. 